\title{
EFFECTIVENESS OF SILVER NITRATE COMPARED TO TALC SLURRY AS PLEURAL SCLEROSING AGENT IN RABBITS. INFLUENCE OF CONCOMITANT INTRAPLEURAL LIDOCAINE
}

Francisco S. Vargas, Alipio O. Carmo, Evaldo Marchi, Marcelo A.C. Vaz, Karine P. Ramos, Viviane C. Mattos and Lisete R. Teixeira

VARGAS, FS et al. - Effectiveness of silver nitrate compared to talc slurry as pleural sclerosing agent in rabbits. Influence of concomitant intrapleural lidocaine. Rev. Hosp. Clín. Fac. Med. S. Paulo 54 (6):199-208, 1999.

SUMMARY: The ideal agent for producing pleurodesis has not been identified. Talc, the most commonly used, poses several problems. Another possibility is silver nitrate, which was widely used in the past.

Purpose: To determine the influence of the intrapleural instillation of lidocaine in producing a pleurodesis with silver nitrate, to define the effect of lidocaine in the maturation of the collagen fibers, and to confirm that the pleurodesis after silver nitrate is stronger than after talc.

Methods: We studied three groups of 8 rabbits. Two groups received $0.5 \%$ silver nitrate; in one we had previously injected $0.5 \mathrm{ml}$ of $2 \%$ lidocaine. The third group received $400 \mathrm{mg} / \mathrm{kg}$ talc $(2 \mathrm{ml})$. The animals were sacrificed 28 days after the injection, and the pleural spaces were assessed grossly for evidence of pleurodesis and microscopically for evidence of inflammation and fibrosis. The total amount of pleural collagen and the distribution of thick and thin collagen fibers were quantified. Collagen was identified using picrosirius red stain.

Results: In the two groups that received silver nitrate (without lidocaine: $3.5 \pm 03$ and with lidocaine: $3.2 \pm 0.3$ ), the macroscopic pleurodesis (scale $0-4)$ was significantly $(\mathrm{p}=0.001)$ better than that resulting from talc $(1.6 \pm 0.2)$. The mean degree of pleural fibrosis induced by silver nitrate $(3.5$ $\pm 0.2)$ was significantly $(\mathrm{p}=0.004)$ higher than that induced by talc $(1.9 \pm 0.1)$. The previous instillation of lidocaine resulted in a tendency for decreased amounts of fibrosis $(3.1 \pm 0.4)$. The mean amount $\left(10^{3} \mathrm{~mm}^{2}\right)$ of pleural collagen was significantly $(\mathrm{p}=0.009)$ greater in the rabbits that received silver nitrate $(116.9 \pm 22.7)$ than in those that received talc $(10.7 \pm 3.4)$. The injection of lidocaine slightly reduced the collagen $(80.1 \pm 30.3)$. The distribution of collagen fibers did not differ among the groups.

Conclusion: This rabbit model clearly confirms that intrapleural silver nitrate is more effective than talc for producing pleurodesis. The previous intrapleural instillation of lidocaine results in a decreasing trend in the amount of collagen, but does not change the effectiveness of the pleural fusion or modify the process of collagen maturation.

DESCRIPTORS: Pleurodesis. Talc. Silver nitrate. Pleural effusion. Lidocaine. Collagen.

Pleurodesis is observed when a fibrotic process between the parietal and visceral pleura occurs as the response to a sclerosing agent injected into the pleural space ${ }^{1}$. Currently, talc is accepted by many as the agent of choice for patients with a malignant pleural effusion. Talc is popular for several reasons: a) it is effective in the experimental situation ${ }^{2}$, b) in humans it is apparently more effective than tetracycline derivatives $^{3}$, c) its administration did not interfere with chemotherapy ${ }^{4}, d$ ) it is widely available ${ }^{5}$, and e) it is less ex- pensive than other sclerosing agents ${ }^{5}$. However, there are concerns: a) acute respiratory distress syndrome develops in up to $8 \%$ of patients $s^{6,7}$, and b) the mortality due to the intrapleural administration is about $1 \%$,

Silver nitrate is also inexpensive and widely available. It was used in the past with success ${ }^{8-10}$ and abandoned in the 1980s for no clear reasons, prob-

From the Division of Respiratory Diseases INCOR, University of São Paulo School of Medicine, São Paulo - Brazil. ably due to severe side effects, mainly chest pain requiring large doses of opiates ${ }^{11}$. The morbidity previously encountered apparently was due to the high concentrations used $(1 \%-10 \%)$. In experimental studies in rabbits, we demonstrated that the intrapleural administration of $0.5 \%$ silver nitrate produces a pleurodesis that is comparable to that produced by tetracycline ${ }^{12}$ and that is better than the pleural sclerosis produced by talc ${ }^{13}$.

To minimize the intensity of pain, local anesthesia by injecting lidocaine 
into the pleural space has been suggested. However, in an experimental study in rabbits, we demonstrated that the intrapleural administration of lidocaine (Lido), reduces the effectiveness of pleurodesis when the sclerosing agent is sodium hydroxide ${ }^{14}$.

The objectives of the present study are: a) to confirm the previous observation ${ }^{13}$ that the pleurodesis obtained with silver nitrate is stronger than that observed after talc and that the distribution of collagen fibers is similar with both agents and $b$ ) to assess whether lidocaine injected intrapleurally before silver nitrate has any effect on the subsequent pleurodesis.

\section{METHODS}

The methods have been described in previous studies ${ }^{12,15}$. New Zealand white rabbits weighing 2.0 to $2.5 \mathrm{~kg}$ were anesthetized with an intramuscular injection of ketamine hydrochloride $(35 \mathrm{mg} / \mathrm{kg}$ ) plus xylazine hydrochloride $(5 \mathrm{mg} / \mathrm{kg})$. The thorax was prepared for aseptic surgery by shaving the right chest wall and then cleaning it with povidone-iodine. A 2-cm skin incision was made midway between the spine and the sternum. The muscles in the seventh or eighth intercostal space were bluntly dissected to allow visualization of the parietal pleura. The sclerosant was injected under direct visualization. In sequence, the muscle and the skin were sutured. After the surgery, the rabbits were monitored for clinical evidence of pain (vocalization, tachypnea, and restlessness). Rabbits showing signs of distress were given buprenorphine hydrochloride $0.05 \mathrm{mg}$ / $\mathrm{kg}$, subcutaneously. The study was approved by the Ethics Committee of the Heart Institute (InCor), University of São Paulo Medical School, which oversees research involving both animals and humans.

The rabbits were divided in three groups of 8 animals. Two groups received $2 \mathrm{ml}$ of $0.5 \%$ silver nitrate (SN, $\mathrm{AgNO}_{3}$ - Merck, Germany); in one of these two groups we injected $0.5 \mathrm{ml}$ of $2 \%$ lidocaine hydrochloride 3-5 minutes before receiving $\mathrm{SN}$. The third group received $400 \mathrm{mg} / \mathrm{kg}$ of sterilized talc in $2 \mathrm{ml}$ of saline. The talc was asbestos free, with a mean particle size of $25.4 \mathrm{~mm}$ (90\% percentile of 50.5 $\mathrm{mm})$, contaminated with minute amounts of dolomite, kaolite, cholrite and forsterite (Xilolite, Brazil). The talc slurry was gently shaken immediately before injection.

Rabbits were sacrificed 28 days after the procedure by a lethal injection of pentobarbital into the marginal ear vein. The thorax was removed en bloc. The lung was expanded by the injection of $10 \%$ formalin intratracheally. Then the trachea was ligated, and the entire thorax was submerged in $10 \%$ neutral buffered formalin for at least $48 \mathrm{~h}$.

Necropsy was performed by two of the investigators, who were blinded to the treatment group. Each pleural cavity was carefully exposed by making bilateral incisions through the diaphragms and all the ribs in approximately the midclavicular line. In this manner, the sternum and the medial portions of the anterior ribs were removed to allow evaluation of the pleural cavities. The left hemithorax received no injection and was used as a control.

The macroscopic pleurodesis was graded according to the following scheme: 0 - normal pleural space; 1 less than three adhesions; 2 - more than three adhesions, but localized; 3 - generalized scattered adhesions and 4 - complete obliteration of pleural space by adhesions.

The presence of hemothorax was graded on a zero to 4 scale; 0 meaning no hemothorax, 1 indicating a hemothorax involving less than $15 \%$ of the hemithorax, 2 indicating involvement of from $15 \%$ to $33 \%, 3$ indicating involve- ment of from 33 to $75 \%$, and 4 indicating greater than $75 \%$ involvement. At gross examination, the diagnosis of hemothorax was made if there were blood clots in the pleural space. Atelectasis was classified as none (0), partial (1) or complete (2). Mediastinal shift was classified as none (0), slight (1), moderate (2) or severe (3).

Samples of the visceral pleura and lung from each hemithorax were obtained and placed in neutral buffered $10 \%$ formalin. These tissue samples for histologic examination were processed routinely and stained with hematoxylineosin and picrosirius ${ }^{16,17}$. The degree of microscopic inflammation and fibrosis was defined from the hematoxylin-eosin slides, and the total collagen was determined from picrosirius red-stained slides. The microscopic slides were evaluated by two of the investigators who were blinded to the treatment. The inflammation and fibrosis were graded as none (0), equivocal (1), mild (2), moderate (3) or severe (4). Collagen fibers were subdivided into thick and thin fibers after picrosirius red staining ${ }^{16}$. The enhancement of collagen birefringence elicited by picrosirius staining is specific for collagen. Thin (immature) fibers are green and weakly birefringent, while thick (mature) fibers are yellow and strongly birefringent ${ }^{18}$.

Both collagen and fibers were measured using a Leica Q500IW Imaging Workstation provided with an Image Processing and Analysis System (Leica Imaging Systems Ltd), which allows quantitative geometric and densitometric measurements.

Pleural thickening, defined as the distance between the edges of the pleura and the fibrosis, delimited the area that was analyzed in six different regions. The final result is the mean of the measures. The Leica System, which detects color images and enables pixel - micron conversion, was used to measure the total collagen and quantify the percentage of thin and thick fibers. 
Statistical Analysis: All data are expressed as the mean \pm SEM. One-way analysis of variance (ANOVA) was used to compared the data among the groups (Sigma Stat; Jandel Scientific). Differences in the results were considered significant when $\mathrm{p}<0.05$.

\section{RESULTS}

The intrapleural instillation of silver nitrate with or without lidocaine resulted in a significantly greater degree of pleurodesis than did talc slurry (Table 1). The mean pleurodesis score after the intrapleural injection of $0.5 \%$ silver nitrate alone $(3.5 \pm 0.3)$ or with lidocaine $(3.2 \pm 0.3)$ was significantly higher $(\mathrm{p}=0.001)$ than that obtained after talc $(1.6 \pm 0.2)$ (Fig 1). Seven of eight rabbits $(87.5 \%)$ that received silver nitrate alone and five of eight $(62.5 \%)$ that also received lidocaine had an effective pleurodesis (score 3 or 4 ), and no rabbit with talc had a score above 2. The scores on the left hemithorax were 0 for all the animals (Table 2).

The intrapleural injection of silver nitrate resulted in significantly $(\mathrm{p}=$
0.004) more mediastinal shift $(1.9 \pm$ $0.4)$ than the intrapleural injection of talc slurry $(0.0 \pm 0.0)$. The mediastinal shift after the administration of silver nitrate and lidocaine $(0.6 \pm 0.4)$ was minimal. There were two rabbits with hemothorax (grade 2 and 3) in the silver nitrate group and two (grade 1) in the silver nitrate plus lidocaine group. Six of the eight $(75 \%)$ rabbits that received silver nitrate and two of the eight $(25 \%)$ that received silver nitrate plus lidocaine had grade 2 or higher atelectasis of the ipsilateral lung, while none of the rabbits that received talc had any atelectasis (Table 1). On the control side, no rabbit in either group developed mediastinal shift, atelectasis, or hemothorax (Table 2).

When the pleura was examined microscopically, the intrapleural administration of silver nitrate without lidocaine also resulted in more fibrosis (Table 1). The degree of pleural fibrosis after the administration of $0.5 \%$ silver nitrate alone $(3.5 \pm 0.2)$ was significantly greater $(\mathrm{p}=0.004)$ than that after talc $(1.9 \pm 0.1)$. There was no statistical differences after injection of silver nitrate and lidocaine $(3.1 \pm 0.4)$ (Fig 1). The degree of pleural inflam- mation on the injected side (Table 1) was similar in all groups $(\mathrm{p}=0.459)$. The mean degree of alveolar inflammation and fibrosis was also significantly higher in the silver nitrate group than in the talc group (Table 1). There was no statistical difference after silver nitrate with lidocaine. On the control side (Table 2), rabbits in the silver nitrate group had significantly more pleural inflammation $(\mathrm{p}=0.005)$ and fibrosis $(p=0.009)$ than those in the talc group; however, no differences were seen in the silver nitrate plus lidocaine group.

The total production of pleural collagen (Table 1, Fig 2) was higher ( $p=$ $0.009)$ after silver nitrate $(116.9 \pm 22.7$ $\left.10^{3} \mathrm{~mm}^{2}\right)$ than after talc $(10.7 \pm 3.4$ $\left.10^{3} \mathrm{~mm}^{2}\right)$; no statistical differences were observed in the group that also received lidocaine, as compared to the talc group $\left(80.1 \pm 30.310^{3} \mathrm{~mm}^{2}\right)$. Thus, previous intrapleural injection lidocaine resulted in a tendency for decreased pleural fibrosis and deposition of collagen (Fig 3). After 28 days of the intrapleural injection of the sclerosing agents, the pleurodesis observed showed the predominance of mature (thick) fibers in all groups. There were

Table 1 - Results from macroscopic and microscopic examination of the right side after the intrapleural instillation of the sclerosant (Mean \pm SEM).

\begin{tabular}{|c|c|c|c|c|}
\hline & Silver Nitrate & Silver Nitrate + Lidocaine & Talc & $\mathrm{P}$ \\
\hline \multicolumn{5}{|c|}{ Macroscopic Findings } \\
\hline Pleurodesis (Score) $\# *$ & $3.5 \pm 0.3$ & $3.2 \pm 0.3$ & $1.6 \pm 0.2$ & 0.001 \\
\hline Right Mediastinal Shift (Score) $*$ & $1.9 \pm 0.4$ & $0.6 \pm 0.4$ & $0.0 \pm 0.0$ & 0.004 \\
\hline Hemothorax (Score) & $0.6 \pm 0.4$ & $0.1 \pm 0.1$ & $0.0 \pm 0.0$ & 0.305 \\
\hline Atelectasis (Score) $*$ & $2.4 \pm 0.5$ & $0.9 \pm 0.5$ & $0.0 \pm 0.0$ & 0.003 \\
\hline \multicolumn{5}{|c|}{ Microscopic Findings } \\
\hline \multicolumn{5}{|l|}{ Pleural (Score) } \\
\hline Inflammation & $2.2 \pm 0.1$ & $2.1 \pm 0.4$ & $1.7 \pm 0.3$ & 0.459 \\
\hline Fibrosis * & $3.5 \pm 0.2$ & $3.1 \pm 0.4$ & $1.9 \pm 0.1$ & 0.004 \\
\hline \multicolumn{5}{|l|}{ Alveolar (Score) } \\
\hline Inflammation $*$ & $2.2 \pm 0.3$ & $1.6 \pm 0.4$ & $0.1 \pm 0.1$ & 0.001 \\
\hline Fibrosis * & $1.2 \pm 0.1$ & $0.7 \pm 0.1$ & $0.0 \pm 0.0$ & $<0.001$ \\
\hline \multicolumn{5}{|l|}{ Collagen } \\
\hline Total $\left(10^{3} \mathrm{~mm}^{2}\right) *$ & $116.9 \pm 22.7$ & $80.1 \pm 30.3$ & $10.7 \pm 3.4$ & 0.009 \\
\hline Thin Fibers $(\%)$ & $33.4 \pm 3.7$ & $35.6 \pm 5.1$ & $46.5 \pm 5.9$ & 0.165 \\
\hline Thick Fibers (\%) & $66.6 \pm 3.6$ & $64.4 \pm 15.4$ & $53.5 \pm 5.8$ & 0.165 \\
\hline
\end{tabular}

* (Silver Nitrate) $x$ (Talc) \# (Silver Nitrate + Lidocaine) x (Talc) 


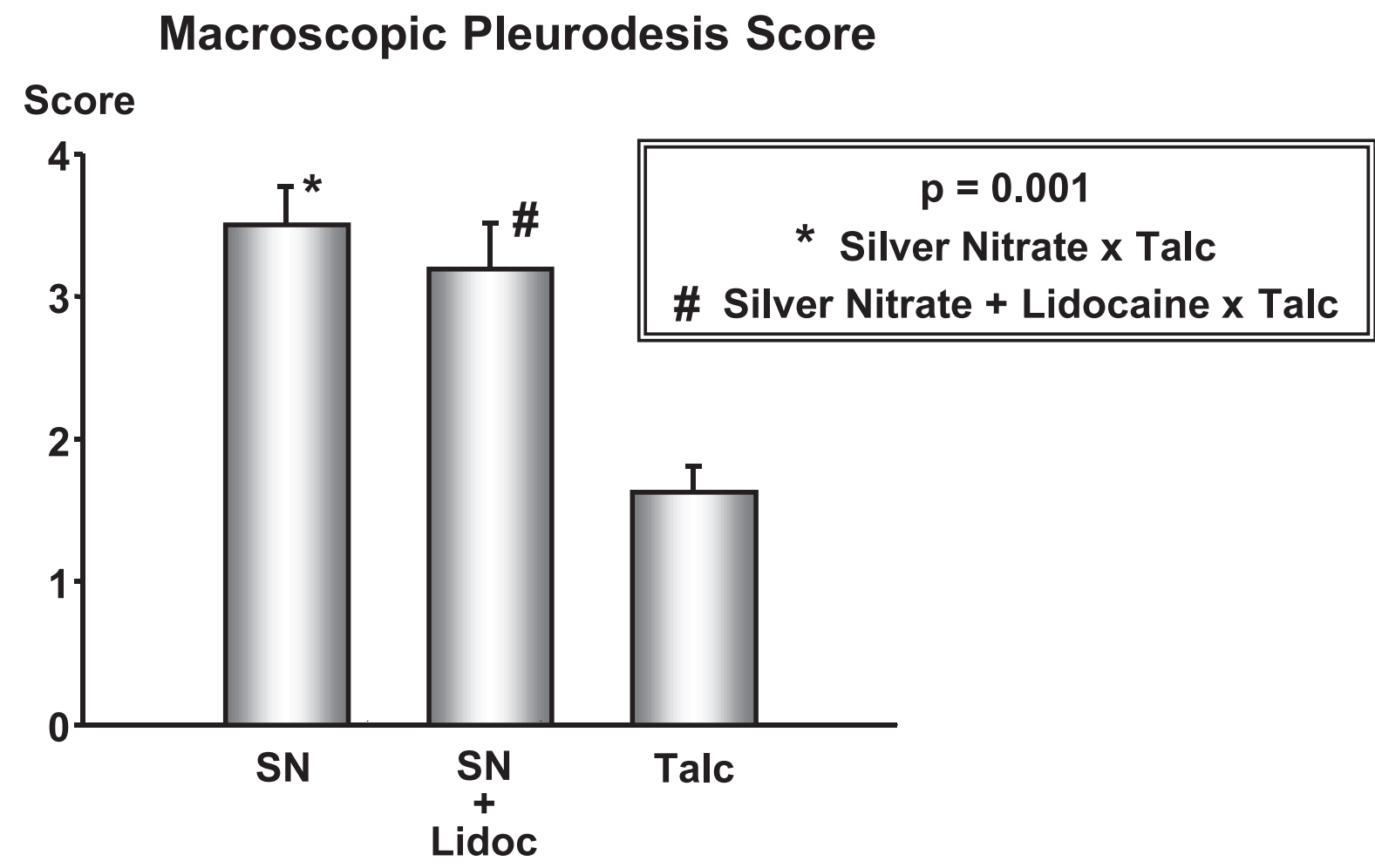

Microscopic Pleural Scores

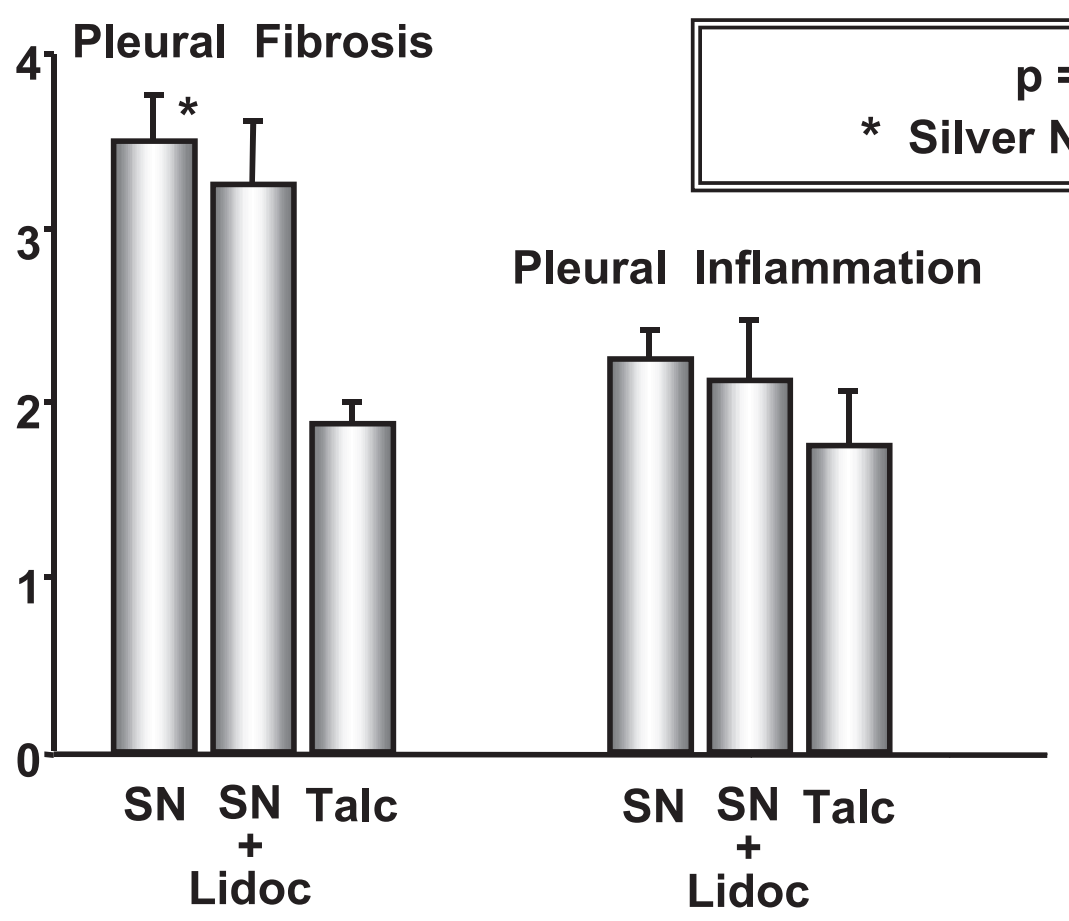

Figure 1 - Comparison of macro and microscopic scores on the right side (Mean \pm SEM). 


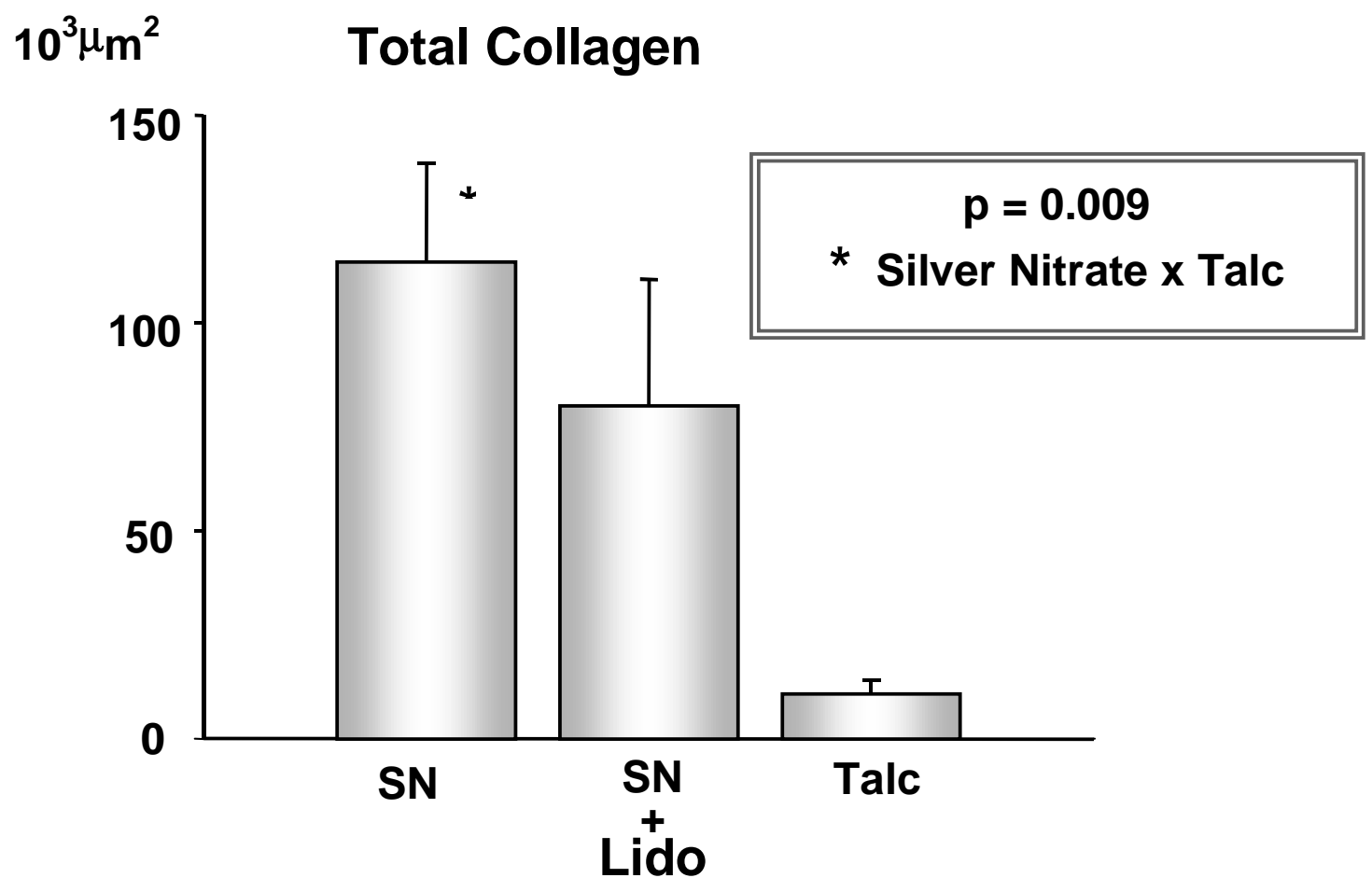

\section{$\% \quad$ Collagen Fibers}

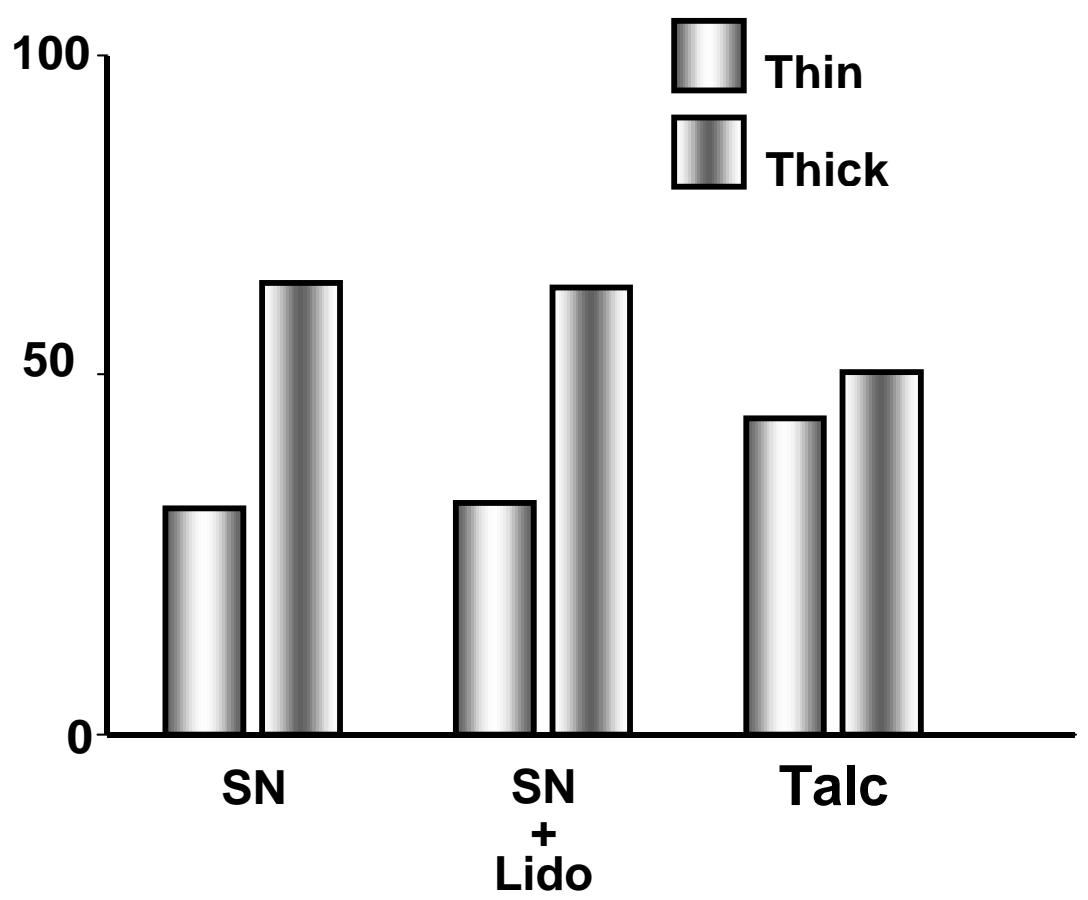

Figure 2 - Comparison of pleural fibrosis and pleural inflammation on right side in the studied groups: talc, silver nitrate and silver nitrate plus lidocaine $($ Mean + SEM) 


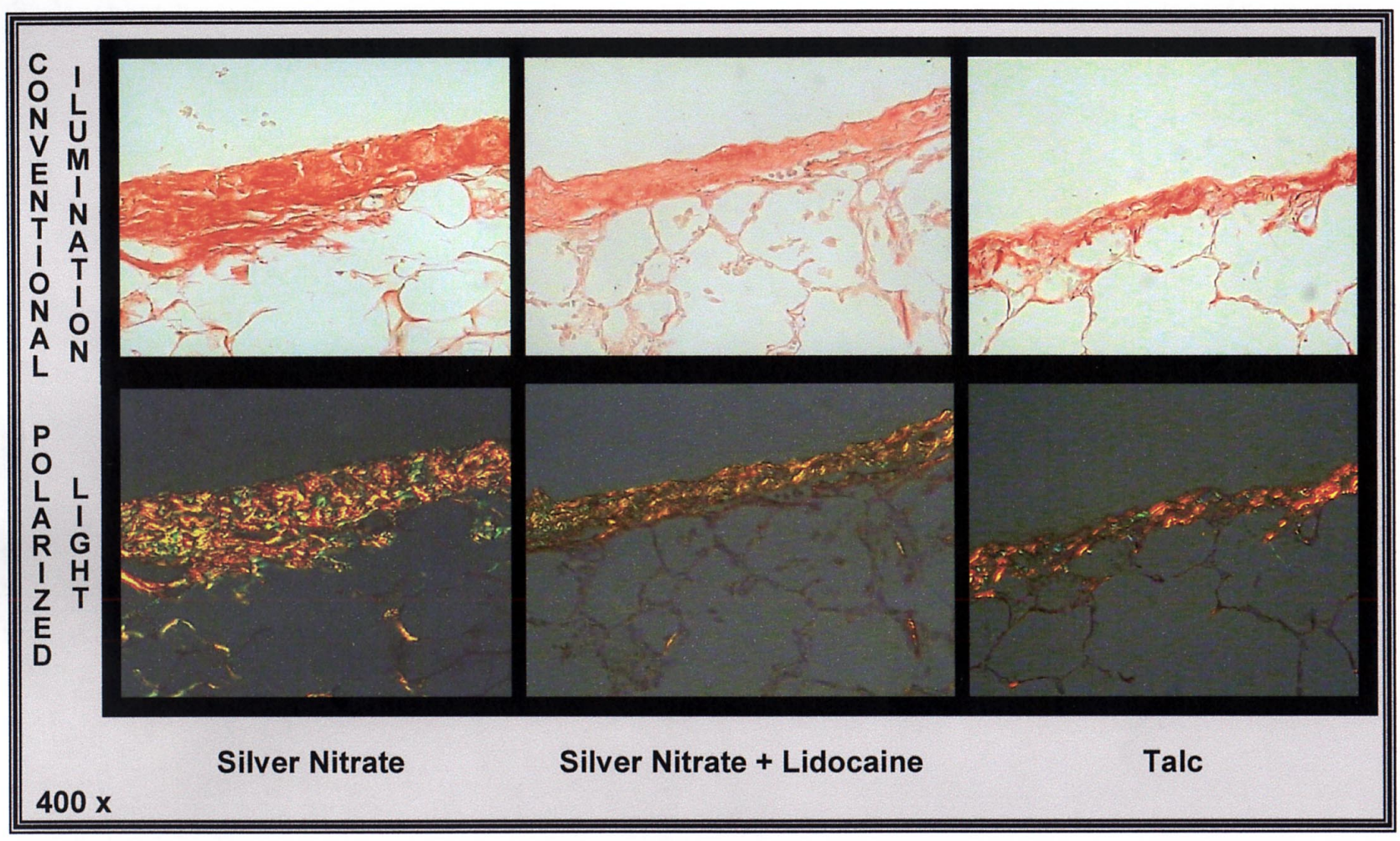

Figure 3 - Photomicrografs of tissue sections obtained from the pleural fibrosis stained with picrosirius and observed under conventional ilumination and polarized light.

Table 2 - Results from macroscopic and microscopic examination of the left side after the intrapleural instillation of the sclerosant (Mean \pm SEM).

\begin{tabular}{|c|c|c|c|c|}
\hline & Silver Nitrate & Silver Nitrate + Lidocaine & Talc & $\mathrm{P}$ \\
\hline \multicolumn{5}{|c|}{ Macroscopic Findings } \\
\hline Pleurodesis (Score) & $0.0 \pm 0.0$ & $0.0 \pm 0.0$ & $0.0 \pm 0.0$ & 1.000 \\
\hline Left Mediastinal Shift (Score) & $0.0 \pm 0.0$ & $0.0 \pm 0.0$ & $0.0 \pm 0.0$ & 1.000 \\
\hline Hemothorax (Score) & $0.0 \pm 0.0$ & $0.0 \pm 0.0$ & $0.0 \pm 0.0$ & 1.000 \\
\hline Atelectasis (Score) & $0.0 \pm 0.0$ & $0.0 \pm 0.0$ & $0.0 \pm 0.0$ & 1.000 \\
\hline \multicolumn{5}{|c|}{ Microscopic Findings } \\
\hline \multicolumn{5}{|l|}{ Pleural (Score) } \\
\hline Inflammation * & $0.9 \pm 0.1$ & $0.5 \pm 0.2$ & $0.0 \pm 0.0$ & 0.005 \\
\hline Fibrosis * & $1.0 \pm 0.3$ & $0.4 \pm 0.2$ & $0.0 \pm 0.0$ & 0.009 \\
\hline \multicolumn{5}{|l|}{ Alveolar (Score) } \\
\hline Inflammation * & $0.8 \pm 0.2$ & $0.1 \pm 0.1$ & $0.0 \pm 0.0$ & 0.002 \\
\hline Fibrosis & $0.1 \pm 0.1$ & $0.0 \pm 0.0$ & $0.0 \pm 0.0$ & 0.368 \\
\hline \multicolumn{5}{|l|}{ Collagen } \\
\hline Total $\left(10^{3} \mathrm{~mm}^{2}\right)$ & $1.7 \pm 2.5$ & $2.0 \pm 2.4$ & $1.8 \pm 0.9$ & 0.877 \\
\hline Thin Fibers (\%) & $50.8 \pm 9.4$ & $44.0 \pm 0.8$ & $38.4 \pm 5.6$ & 0.413 \\
\hline Thick Fibers (\%) & $49.2 \pm 9.4$ & $56.0 \pm 0.8$ & $61.6 \pm 5.6$ & 0.413 \\
\hline
\end{tabular}

\footnotetext{
* (Silver Nitrate) $\mathrm{x}($ Talc $)$
} 
no statistical differences $(\mathrm{p}=0.165)$ regarding the distribution between thin or thick fibers among the groups (Fig 2 ). On the left side, the amount of collagen was minimal with no statistical differences.

The intrapleural administration of silver nitrate (with or without lidocaine) or talc slurry was well tolerated; distress was not observed in any of the animals. Only one rabbit in the silver nitrate group died during the anesthesia. After the intrapleural injection of the sclerosing agent, the animals maintained normal feeding and activities. The rabbits did not require medication for vocalization, tachypnea, or restlessness.

\section{DISCUSSION}

This study confirms that in the rabbit model, $0.5 \%$ silver nitrate $(2 \mathrm{ml})$ is more effective than $2 \mathrm{ml}$ of talc slurry $(400 \mathrm{mg} / \mathrm{kg})$ in producing a pleurodesis $^{13}$. The study also shows that previous intrapleural injection $(0.5 \mathrm{ml})$ of $2 \%$ lidocaine results in a tendency for decreasing pleural fibrosis and deposition of collagen. However, local anesthesia does not modify the macroscopic fusion between the visceral and parietal pleura or the maturation of collagen represented by the proportion between thin and thick fibers.

The ideal agent for producing pleurodesis has not been identified. Talc appears to be the most effective agent, but recently it has been associated with ARDS $^{19,20}$. Bleomycin is expensive and less effective than the other agents. Tetracycline is unavailable, and the tetracycline derivatives are expensive, painful, and not available throughout the world ${ }^{3}$.

Silver nitrate was one of the first agents used for pleurodesis; more than 50 years ago, Brock ${ }^{21}$ proposed its use to create an aseptic obliterative pleurodesis. Since then, there have been several reports with contradictory results.
Previous studies in the rabbit model have shown that silver nitrate is as effective as tetracycline ${ }^{22}$ and more effective than $\operatorname{talc}^{13}$ in producing pleurodesis. The primary advantages of silver nitrate are its low cost and wide accessibility; the disadvantages are the severity of the side effects, mainly chest pain and pleural exudation.

The mechanism responsible for the pleurodesis that follows intrapleural administration of the sclerosing agents is incompletely understood. The first event between the intrapleural injection and the fusion of the visceral and parietal pleura appears to be the injury manifested by the denudation of mesothelial cells $^{23}$ and the development of an exudative pleural effusion ${ }^{24}$. The reparation of pleural tissue involves several processes: acute inflammation (day 1), regeneration of the damaged cells, migration of connective tissue cells to the damaged area (days 3-5), synthesis of extracellular matrix (ECM) proteins (days to weeks), and deposition of collagen $\left(1^{\text {st }} \text { week to several weeks }\right)^{25}$.

Collagen is the most important protein in the production of pleurodesis. The first step in the synthesis of collagen occurs in the fibroblasts and is represented by the synthesis of propeptides; while intracellular they aggregate to form procollagen molecules ${ }^{25}$. These molecules are subsequently secreted, and in the extracellular space, they aggregate to form fibrils called tropocollagen. The next step is the oxidation of tropocollagen molecules ${ }^{25}$ and formation of thin immature collagen fibers ${ }^{16}$. These thin collagen fibers will mature reacting with other collagen fibers to become thick mature collagen fibers ${ }^{16}$ responsible for the resistance of the visceral pleura to stretching ${ }^{26}$.

Several factors should be considered regarding the process occurring from the instillation of the sclerosing agent to the tissue repair or the development of a pleurodesis. The mesothelial cell is crucial: the injury represents the first step-the greater the injury, the more likely is the probability of developing a pleurodesis ${ }^{12}$; the mesothelial cell is also involved in the repair process $^{27}$. Mesothelial cells secrete collagen and enzymes such as metalloproteinases, which degrade collagen, and inhibitors of the metalloproteinases ${ }^{27}$. Pleurodesis or tissue repair depends on the balance between the pro-collagen and the anti-collagen factors, if procollagen factors are predominant, pleurodesis will occur.

In the development of this study, we planned to confirm that the pleurodesis with silver nitrate is stronger than that with talc and to clarify whether there is a similar percentage of mature and immature collagen fibers in both silver nitrate and the talc pleurodesis. We also hypothesized that previous intrapleural injection of lidocaine would decrease the effectiveness of pleurodesis and that lidocaine would impair the maturation of the collagen fibers.

This research ratifies that a low concentration of silver nitrate $(0.5 \%)$ is more effective than talc $(400 \mathrm{mg} / \mathrm{kg})$ in producing a pleurodesis in rabbits. Silver nitrate produces a greater degree of macro- and microscopic fibrosis. The research also confirms that the pleurodesis following intrapleural injection of either silver nitrate or talc is characterized by a similar distribution of collagen fiber types. Although the total amount of collagen fibers was significantly greater after silver nitrate (116.9 $\left.\mathrm{mm}^{2}\right)$ than after talc $\left(10.7 \mathrm{~mm}^{2}\right)$, the proportion of thick fibers was similar after silver nitrate $(66.6 \%)$ or after talc $(53.5 \%)$. The likely explanation for this evidence is that the biologic pleural changes to the sclerosing agents are not specific; they are dependent only of the initial degree of the injury. Corroborating this interpretation is that the level of pleural inflammation after 28 days was similar after either silver nitrate (2.2) or talc (1.7). Only the lung tissue showed persistence of a residual, but 
higher inflammation (2.2) and fibrosis (1.2) after silver nitrate; after talc, the lung was normal.

The effect of lidocaine in the production of a pleurodesis is interesting. The previous intrapleural instillation of $0.5 \mathrm{ml}$ of $2 \%$ lidocaine resulted in a strong tendency for a decrease in the degree of macro- and microscopic pleurodesis, but the change did not reach statistical significance. The proportion of thin to thick collagen fibers was not modified.

Several mechanisms should be considered to explain these effects. Lidocaine hydrochloride combines chemically with silver nitrate to form $\mathrm{AgCl}$ and lidocaine. When lidocaine hydrochloride and silver nitrate are mixed in a test tube in the proportions used in this protocol, a white salt settles out in the bottom of the mixture. This certainly indicates that some of the silver nitrate is being deactivated, and the amount of the active sclerosant is decreasing. As this study only shows a tendency to decrease the effectiveness, we believe that the injection of larger volumes of lidocaine would reduce the degree of pleurodesis.

Another possibility is that lidocaine might influence the results by increasing the total volume injected and diluting the silver nitrate. This possibility is unlikely since the volume of lidocaine injected was only $0.5 \mathrm{ml}$ and since previous studies with minocycline showed that at the same dose, the pleurodesis with larger volumes was stronger ${ }^{28}$.

Finally, the combination of lidocaine with silver nitrate may change the $\mathrm{pH}$. However, the addition of lidocaine hydrochloride to silver nitrate does not affect the $\mathrm{pH}$ very much. The $\mathrm{pH}$ of silver nitrate is 5.32 and of lidocaine 6.73 . When $0.5 \mathrm{ml}$ of lidocaine hydrochloride is mixed with $2 \mathrm{ml}$ of $0.5 \%$ silver nitrate, the $\mathrm{pH}$ changes to 5.68, and no significant changes in the serial $\mathrm{pH}$ measurements are observed in this mixture over a 60-minute period. It should be mentioned that Sahn and Good could not demonstrate a relationship between the $\mathrm{pH}$ of the sclerosing agent and its effectiveness as a sclerosant ${ }^{24}$.

Silver nitrate was used in the 1980 s to induce pleurodesis and abandoned due to severe side effects including severe chest pain and the formation of a large pleural exudation. This study suggests that the intrapleural administration of $2 \mathrm{ml}$ of $0.5 \%$ silver nitrate produces few side effects. None of the rabbits appeared distressed after receiving silver nitrate, and all of them resumed a normal feeding pattern and normal activities after administration of silver nitrate.

The local side effects represented by mediastinal shift, presence of atelectasis, and the occurrence of hemothoraces in the silver nitrate group are not disconcerting; these changes are less than those observed after the intrapleural administration of the tetracycline deriva- tives $^{12}$. With the tetracycline derivatives, these complications can be prevented by inserting a chest tube. Our animals did not receive chest tubes.

In conclusion, the present study confirms that $0.5 \%$ silver nitrate is more effective than $400 \mathrm{mg} / \mathrm{kg}$ of talc in producing a pleurodesis in rabbits. The intrapleural administration of silver nitrate produced a greater degree of macroscopic pleurodesis with a greater amount of microscopic fibrosis and collagen formation. A previous intrapleural injection of $0.5 \mathrm{ml}$ lidocaine resulted in a tendency for decreased the fibrosis and collagen formation. The proportion between thin and thick collagen fibers is similar with either talc or silver nitrate. The previous intrapleural administration of lidocaine did not change the proportion of the collagen fibers.

Considering that silver nitrate is inexpensive, widely available and produces an effective pleurodesis without significant side effects in rabbits, we suggest that an evaluation in humans should be undertaken. However intrapleural anesthesia with lidocaine should be avoided.

ACKNOWLEDGEMENTS: This study was supported by $\mathrm{CNPq}$ and FAPESP. The authors would like to thank the assistance of Dr. Roberto Onishi and Solange Aparecida Consorti.
VARGAS, FS e col. - A eficiência da injeção intrapleural de lidocaina na produção de pleurodese com nitrato de prata. Uma comparação entre a pleurodese produzida pelo nitrato de prata e a injeção intrapleural de talco. Rev. Hosp. Clín. Fac. Med. S. Paulo 54 (6):199-208, 1999.
Não está ainda definido, qual o agente ideal para a produção de uma pleurodese efetiva. $\mathrm{O}$ talco é o agente mais freqüientemente utilizado apesar de suas manifestações colaterais. Outra possibilidade é o nitrato de prata, largamente usado no passado.

Objetivos: Determinar a influência da injeção intrapleural de lidocaina na produção de pleurodese com nitrato de prata, definir o efeito da lidocaina na maturação das fibras colágenas e confirmar que a pleurodese produzida pelo nitrato de prata é mais potente que a conseqüente à injeção intrapleural de talco. 
Métodos: Foram estudados três grupos de 8 coelhos. Dois receberam nitrato de prata a $0,5 \%$; em um deles, foi injetado previamente $0,5 \mathrm{ml}$ de lidocaina a $2 \%$. O terceiro grupo recebeu $2 \mathrm{ml}$ de talco $(400 \mathrm{mg} / \mathrm{kg})$. Os animais foram sacrificados após 28 dias da injeção intrapleural e as cavidades pleurais examinadas macroscopicamente, analisando-se a presença de fusão entre os folhetos pleurais e microscopicamente avaliando-se a inflamação e a fibrose. Quantificou-se o total de colágeno na pleura e a distribuição de fibras finas e grossas, utilizando-se a coloração de pricrosirius.

Resultados: Nos dois grupos em que se injetou nitrato de prata (s/ lidocaina: $3.5 \pm 0.3$ e com lidocaina: $3.2 \pm 0.3)$, a pleurodese macroscópica (scala 0 - 4) foi significantemente $(\mathrm{p}=$ $0.001)$ melhor do que a pleurodese resultante do talco $(1.6 \pm 0.2)$. A média da fibrose pleural induzida pelo nitrato de prata $(3.5 \pm 0.2)$ foi significantemente $(\mathrm{p}=0.004)$ mais acentuada do que a produzida por talco $(1.9 \pm 0.1)$. A instilação prévia de lidocaina determinou tendência a diminuir a quantidade de fibrose $(3.1 \pm 0.4)$. A média $\left(10^{3} \mathrm{~mm}^{2}\right)$ do colágeno pleural foi significantemente $(\mathrm{p}=0.009)$ maior nos coelhos que receberam nitrato de prata $(116.9 \pm 22.7)$ do que naqueles que receberam talco $(10.7 \pm 3.4)$. A in- jeção de lidocaina reduziu discretamente o colágeno $(80.1 \pm 30.3)$. A distribuição das fibras colágenas não foi diferente entre os grupos estudados.

Conclusão: Este modelo animal confirma que, o nitrato de prata injetado no espaço pleural mais efetivo do que o talco na produção de pleurodese. A injeção intrapleural de lidocaina determina uma tendência a reduzir a quantidade de colágeno, mas não muda a efetividade da sínfise pleural ou modifica a maturação do colágeno.

DESCRITORES: Pleurodese. Talco. Nitrato de prata. Efusão Pleural. Lidocaina. Colágeno.

\section{REFERENCES}

1. LIGHT RW \& VARGAS FS - Pleural sclerosis for the treatment of pneumothorax and pleuraleffusion. Lung 1997; 175:213-223.

2. XIE C, TEIXEIRA LR, WANG $\mathrm{N}$ et al. - Serial observations after high dose talc slurry in the rabbit model for pleurodesis. Lung 1998; 176:299-307.

3. WALKER-RENARD PB, VAUGHAN LM \& SAHN SA - Chemical pleurodesis for malignant pleural effusions. Ann Intern Med. 1994; 120:56-64

4. ADLER RH \& SAYER I - Treatment of malignant pleural effusion: a method using tube thoracostomy and talc. Ann Thorac Surg 1976; 22:8-15.

5. KENNEDY L, RUSH VW, STRANGE C et al. Pleurodesis using talc slurry. Chest 1994; 106:342-346.

6. MILANEZ CAMPOS JR, WEREBE EC, VARGAS FS et al. Respiratory failure due to insufflated talc. Lancet 1997; 349:251252.

7. REHSE DH, AYE RW \& FLORENCE MG - Respiratory failure following talc pleurodesis. Am J Surg. 1999; 177:437-440.

8. WIED U, ANDERSEN K, SCHULTZ A et al. - Silver nitrate pleurodesis in spontaneous pneumothorax. Scand J Thor Cardiovasc Surg 1981; 15:305-307

9. WIED U, HALKIER E, HOEIER-MADSEN K et al. Tetracycline versus silver nitrate in pleurodesis in spontaneous pneumothorax. J Thorac Cardiovasc Surg 1983; 86:591-593.
10. ANDERSEN J \& NISSEN H - Results of silver nitrate pleurodesis in spontaneous pneumothorax. Chest 1968; 54:230-233.

11. WIED U, HALKIER E, HOEIER-MADSEN K et al. - Tetracycline versus silver nitrate pleurodesis in spontaneous pneumothorax. J Thorac Cardiovasc Surg 1983; 86:591-593.

12. VARGAS FS, TEIXEIRA LR, SILVA LM et al. - Comparison of silver nitrate and tetracycline as pleural sclerosing agents in rabbits. Chest 1995; 108:1080-1083.

13. VARGAS FS, TEIXEIRA LR, LIGHT RW, et al. - Silver nitrate is superior to talc slurry in producing pleurodesis in rabbits. Chest (in press).

14. TEIXEIRA LR, VARGAS FS, CARMO AO et al. - Effectiveness of sodium hydroxide as a pleural sclerosing agent in rabbits: influence of concomitant intrapleural lidocaine. Lung 1996; 174:325-332.

15. ROGERS JT, CHENG D, WHEELER A et al. - The effects of tumor necrosis factor alpha (TNF) blocking antibody on pleurodesis in rabbits. Chest 1998; 114:260S.

16. ANDRADE GB, RIET-CORREA F, MONTES GS et al. - Dating of fibrotic lesions by the picrosirius-polarization method. An application using the lesions of Lechiguana (bovine focal proliferative fibrogranulomatous panniculitis). Eur J Histochem 1997; 41: 203-209.

17. MALLORY FB - Pathological Technique. Philadelphia, Saunders, 1938. p.152-153. 
18. JUNQUEIRA LC \& MONTES GS - Biology of collagen-proteoglycan interaction. Arch Histol Jap 1983; 46:589-629.

19. RINALDO JE, OWENS GR \& ROGERS RM - Adult Respiratory distress syndrome following intrapleural instillation of talc. $\mathbf{J}$ Thorac Cardiovasc Surg 1983; 85:523-526.

20. BOUCHAMA A, CHASTRE J, GAUDICHET A et al. - Acute pneumonitis with bilateral effusion after talc pleurodesis. Chest 1984; 86:795-797.

21. BROCK RC. The use of silver nitrate in the production of aseptic obliterative pleuritis. Guys Hosp Rep 1942; 91:99-103.

22. VARGAS FS, TEIXEIRA LR, SILVA LM et al. - Comparison of silver nitrate and tetracycline as pleural sclerosing agents in rabbits. Chest 1995; 108:1080-1083.

23. KENNEDY L, HARLEY LA, SHAN SA et al. - Talc slurry pleurodesis. Pleural fluid and histologic analysis. Chest 1995; 107: 1707-1712.
24. SHAN AS \& GOOD JT - The effect of common sclerosing agents on the rabbit pleura space. Am Rev Respir Dis 1981; 124:65-67.

25. COTRAN R, KUMAR V \& COLLINS T - Robbins Pathologic Basis of Disease, $6^{\text {th }}$ ed. Pennsylvania, Saunders,1999. p.89-134.

26. LEMOS M, POZO RMK, SANTIAGO G et al. - Organization of collagen and elastic fibers studied in stretch preparations of whole mounts of human visceral pleura. Ann Anat 1997; 179:447-452.

27. MARSHALL BC, SANTANA A, XU QP et al. - Metalloproteinases and tissue inhibitor of metalloproteinases in mesothelial cells cellular differentiation influences expression. J Clin Invest 1993; 91:1792-1799.

28. LIGHT RW, WANG NS, SASSOON NS et al. - Comparison of the effectiveness of tetracycline and minocycline as pleural sclerosing agents in rabbits. Chest 1994;106:577-582.

Received for publication on the $05 / 01 / 00$ 